\title{
PENILAIAN KEBUTUHAN STANDAR PERHIASAN IMITASI
}

\author{
Assessment of Need forlmitation Jewelry Standard
}

\author{
Joni Setiawan, Istihanah Nurul Eskani, dan Euis Laela \\ Balai Besar Kerajinan dan Batik - Kementerian Perindustrian \\ Jl. Kusumanegara No. 7 Yogyakarta 555166 \\ e-mail: joni-s@kemenperin.go.id
}

\begin{abstract}
Abstrak
Standar Nasional Indonesia (SNI) sebagai alat non tarrif barrier untuk membendung masuknya produk yang kurang berkualitas masuk ke Indonesia perlu ditingkatkan. Pada saat ini ketersediaan SNI produk masih kurang, sebagai contohnya adalah standar bidang perhiasan, khususnya SNI perhiasan imitasi belum ada. Perhiasan imitasi yang beredar diduga mengandung zat yang berbahaya. Zat berbahaya ini jika terus bersentuhan dengan tubuh pemakainya akan bermigrasi ke tubuh dan mengakibatkan berbagai macam penyakit. Tujuan kajian adalah meninjau pentingnya standar perhiasan imitasi berdasarkan bahaya logam - logam berbahaya yang terdapat pada perhiasan imitasi berdasarkan penelitian - penelitian yang pernah dilakukan di luar negeri. Metode yang dipergunakan dalam peneltian ini adalah deskriptif kualitatif melalui review hasil penelitian kandungan logam berbahaya, neraca perdagangan perhiasan imitasi, ketersediaan SNI dan perbandingan standar perhiasan imitasi di luar negeri. Berdasarkan tinjauan aspek - aspek tersebut, terdapat kandungan logam - logam pada perhiasan imitasi yang dapat membahayakan tubuh dan menimbulkan berbagai macam penyakit. Hasil tinjauan dari aspek perdagangan menggambarkan besarnya nilai import perhiasan imitasi dari China maupun dari dunia. Berdasarkan regulasi standar, perhiasan ini belum diatur dalam SNI. Dan beberapa negara telah menerapkan standar migrasi dengan standar EN 71 part 3 yang didobsi oleh ISO menjadi ISO 8124:3 yang diterapkan di Uni Eropa, Internasional, Australia dan New Zeland.
\end{abstract}

Kata kunci: perhiasan, imitasi, Standar Nasional Indonesia (SNI).

\begin{abstract}
The Indonesian National Standard (SNI) as a non-tarrif barrier to stem the entry of products of less quality into Indonesia needs to be improved. At the moment SNI products are still being issued, for example, there are no standards for the field of jewelery, particularly SNI for imitation jewelery. Imitation jewelry issued. This dangerous substance if constantly in contact with the body of the wearer will migrate to the body and run various diseases. The research objective is the most important of jewelry made based on the hazardous metals needed in imitation jewelery based on studies conducted abroad. The method used in this research is descriptive qualitative through a review of the results of banned metal inventory research, imitation trade licensing, SNI regulations and imitation jewelry standard provisions abroad. Based on consideration of these aspects, there are metals in imitation jewelry that can protect the body and cause various diseases. The results of the assessment from the aspect of trade assess the assessment of imitation jewelry imports from China as well as from the world. Based on standard regulations, this jewelery has not been regulated in SNI. And some countries have adopted the standard of use with EN 71 part 3 which wasadopted by ISO to ISO 8124: 3 which is applied in the European Union, International, Australia and New Zealand.
\end{abstract}

Kata kunci: jewelry, imitation, Standar Nasional Indonesia (SNI).

\section{PENDAHULUAN}

Standar merupakan dokumen atau regulasi teknis yang memuat persyaratan, spesifikasi, pentunjuk, atau karakteristik yang dapat digunakan untuk memestikan bahan, produk, proses dan layanan sesuai dengan tujuannya (ISO, 2019). Dalam perdagangan internasional, standar dipergunakan untuk mengatur kualitas barang yang masuk atau keluar dari negara tertentu. Standar dapat dipergunakan sebagai technical barrier, membendung barang - barang yang berkualitas rendah masuk ke Indonesia, termasuk perhiasan imitasi yang diduga mengandung bahan - bahan yang berbahaya bagi tubuh manusia.

Perhiasan sangat dekat dengan dengan kehidupan kita sebagai sarana mendukung penampilan. Beragam jenis perhiasan digemari oleh wanita seperti kalung, gelangm cincin, bros, dan aksesoris lainnya. Bahan baku perhiasan pada umumnya adalah logam mulia seperti emas karena mempunyai nilai ekonomis dan menjadi simbol keabadian dan kecantikan bagi kaum wanita. Bukan hanya desain perhiasan yang dipertimbangkan oleh 
pengguna, namun karena emas mempunyai nilai ekonomi yang terus naik (Dewi, 2010). Pemintaan konsumen perhiasan emas pada kuartal pertama tahun 2016 naik dari 7,2 menjadi 12,6 ton (Street, Gopaul, Kumar, Lu, \& Hewitt, 2017). Berdasarkan data tersebut maka potensi pengembangan industri perhiasan masih cukup besar.

Emas mempunyai nilai jual yang terus naik dari waktu ke waktu, karena permintaan pasar yang lebih besar daripada persediaan (Dewi, 2010). Menurut Worldwhatch (2008) dalam Dewi (2010), sekitar 80\% logam mulia dipergunakan untuk perhiasan, selebihnya dipergunakan untuk industri (Dewi, 2010). Kenaikan harga emas dunia sedikit banyak mempengaruhi minat konsumen perhiasan dan beralih pada perhiasan dengan bahan baku yang lain. Bahan baku selain emas yang sering digunakan untuk perhiasan adalah perak. Untuk kalangan tertentu mungkin masih mempertahankan emas, karena selain untuk perhiasan, emas juga untuk investasi yang aman (Sholeh, 2014). Konsumen dalam memutuskan untuk membeli produk imitasi didasarkan proses pengenalan kebutuhan, pencarian informasi, evaluasi alternatif, keputusan membeli dan perilaku pascapembelian (Faozi \& Mufidah, 2018). Peneliti menduga, keputusan konsumen dalam membeli barang imitasi salah satunya karena naiknya harga perhiasan logam mulia, harga perhiasan imitasi yang murah dan model yang ditawarkan menarik.

Perhiasan imitasi merupakan perhiasan yang menyerupai perhiasan emas atau perak. Bahan baku perhiasan imitasi seringkali menggunakan logam yang lebih murah dari emas dan perak, antara lain tembaga, kuningan, timah dan bahan logam lain yang sesuai. Beberapa logam tersebut bukan termasuk dalam golongan logam mulia sehingga memiliki sifat korosi karena pengaruh lingkungan sekitar. Oleh karena itu memerlukan pelapisan (coating) dengan logam mulia. Tujuan pelapisan ini untuk memperbaiki sifat dan menambahkan keindahan layaknya seperti perhiasan dari logam mulia. Ini sejalan dengan trend berbusana dinamis membutuhkan perhiasan yang beragam dengan harga relatif murah dengan penampilan yang menarik sehingga dapat memungkinkan untuk sering berganti ganti perhiasan. Dibalik bagusnya perhiasan imitasi yang murah, terdapat ancaman bagi kesehatan pemakainya karena ditengarai mengandung bahan - bahan yang berbahaya yang berasal dari logam dasarnya.

Selanjutnya dalam perdagangan internasional, World Trade Organization
(WTO) telah mensepakati adanya Technical Barriers to Trade (TBT) yang mengatur 3 (tiga) hal penting, yaitu: peraturan teknis atau regulasi, standar dan penilaian kesesuaian (Standards and Conformity Assesment). Ketiga instrumen tersebut memberikan jaminan kepada konsumen agar memperoleh barang yang tidak terjangkau dari segi harga dan waktu, namun juga berkualitas dan memenuhi standar kesehatan, keselamatan, keamanan dan lingkungan (K3L) (Sinabutar, 2013). Oleh karena itu apapun produk yang beredar di pasaran harus memenui persyaratan standar kesehatan, keselamatan, keamanan dan lingkungan yang dipersyaratkan melalui standar yaitu Standar Nasional Indonesia (SNI).

Berdasarkan latar belakang di atas maka dirumuskan masalah yaitu apakah ada bahan berbahaya yang terkandung dalam perhiasan imitasi? Berapa nilai perdagangan perhiasan imitasi di Indonesia? Apakah sudah ada regulasi yang mengatur perhiasan imitasi di Indoensia? Dan standar apakah yang sudah berlaku di luar negeri?

Untuk menjawab rumusan masalah ini, maka dilakukan penelitian dengan motode diskriptif kualitatif berupa review hasil penelitian - penelitian terkait dengan kandungan bahan pada perhiasan imitasi yang murah, jenis - jenis bahan berbahaya, pengaruh bahan berbahaya bagi tubuh. Selain itu nilai perdagangan perhiasan imitasi yang diperoleh dari data perdagangan, ketersediaan regulasi standar serta perbandingan standar di luar negeri.

\section{TINJAUAN PUSTAKA}

\section{a. Perhiasan Imitasi}

Terminologi atau definisi perhiasan imitasi adalah sebagai berikut. Dalam kamus besar bahasa Indonesia disebutkan bahwa perhiasan berasal dari per - an + hias (kata benda) yang berarti barang apa yang dipakai untuk berhias: kumpulan nya, seperti cincin, subang, anting-anting, tusuk konde sangat lengkap(KBBI, 2018a). Sedangkan imitasi (kata benda) yang berarti tiruan tiruan; bukan asli: kalung -- , kalung yg dibuat bukan dari emas, tetapi warnanya menyerupai emas(KBBI, 2018b).

Definisi perhiasan imitasi di dalam Cambridge Dictionary Online menyebutkanjewellery (United Kingdom) atau jewelry (United State) (noun) adalah decorative objects worn on clothes or on the body, such as rings and necklaces, often 
made from valuable metals and containing precious stones atau terjemahan bebasnya adalah hiasan yang dikenakan pada pakaian atau tubuh seperti cincin dan kalung, biasanya terbuat dari logam berharga dan mengandung batu mulia(Cambridge, 2018b). Sedangkan imitation adalah made to look like something elsesebagai contohnya adalahan imitation leather jacket. It's not real silk - it's just imitation(Cambridge, 2018a).

Selain berdasarkan pengertian istilah dalam kamus, di dalam sistem perdagangan internasional dikenal sistem penggolongan produk yang diatur dan dikembangkan oleh World Customs Organization (WCO) yaitu sebuah lembaga intergovermental independen berartidi Brussels, Belgia. Sistem ini bernama The Harmonized System (HS). Perhiasan imitasi termasuk dalam HS 7117 Imitation Jewellery. HS 7117 mempunyai sub kategori HS 711719 Perhiasan imitasi dengan bahan dasar logam, HS 711790 Perhiasan imitasi dari bahan dasar non-logam, HS 711711 Cuflinks and studes, mandset dan hiasan kancing(Sinabutar, 2013).

\section{b. Jenis - jenis Perhiasan Imitasi}

Ada berbagai jenis perhiasan seperti cincin, gelang, bross, anting, jepitan rambut, dan lain sebagainya. Sebagaimana telah dijelaskan di atas bahwa sub kategori dari perhiasan imitasi diantaranya adalah perhiasan imitasi berbahan dasar logam, perhiasan imitasi berbahan dasar non-logam dan cuflinks and studes.

Berdasarkan cara pemakaian produk perhiasan imitasi ada yang dipakai dan langsung menempel pada kulit penggunanya seperti kalung, gelang dan cincin, namun ada juga yang tidak langsung menenpel di kulit seperti bross dan hiasan kancing. Untuk produk perhiasan imitasi yang langsung menempel di kulit, jika perhiasan tersebut mengandung logam berbahaya maka akan terjadi migrasi unsur berbahaya tersebut ke tubuh sehingga dapat menyebabkan gangguan metabolisme (Grynkiewicz-bylina, Migracji, Pierwiastk, \& Pow, 2011).

\section{c. Jenis - jenis Logam \\ Berbahaya yang Perlu Dibatasi}

Dalam standar internasional ISO 8124:3 yang diadobsi menjadi SNI ISO 8124-3 2010 tentang SNI Keamanan mainan - Bagian 3: Migrasi unsur tertentu disebutkan batasan kandungan zat berbahaya yaitu $1,4 \mu \mathrm{g}$ antimony, 0,1 $\mu \mathrm{g}$ arsenic, 25,0 $\mu \mathrm{g}$ barium, 0,6 $\mu \mathrm{g}$ cadmium, 0,3 $\mu \mathrm{g}$ chromium, 0,7 $\mu \mathrm{g}$ timbal,
0,5 $\mu \mathrm{g}$ mercury, dan 5,0 $\mu \mathrm{g}$ selenium (ISO, 2010). Pada saat ini SNI ISO 8124-3:2010 masih berlaku pada produk mainan anak, namun tidak menutup kemungkinnan diberlakukan pada perhiasan imitasi. Untuk pemberlakuan pada perhiasan imitasi ini karena diduga adanya kandungan logam berbahaya pada perhiasan imitasi.

Adapun jenis - jenis logam berbahaya seperti antimony (Sb), arsenic (As), barium (Ba), chromium $(\mathrm{Cr})$, timbal $(\mathrm{Pb})$, cadmium (Cd), selenium $(\mathrm{Se})$, mercury $(\mathrm{Hg})$ dan logam berat lainnya. Migrasi elemen mempengaruhi kesehatan anak-anak yang menyebabkan penyakit akut dan kronis tergantung pada jenis dan dosis elemen yang diserap dan bentuknya (sebagai senyawa organik atau anorganik) (Grynkiewicz-bylina et al., 2011).

\section{METODE PENELITIAN}

Untuk menjawab rumusan masalah di atas, maka metode yang digunakan dalam penelitian ini adalah deskriptif kualitatif. Untuk menilai kebutuhan standar perhiasan imitasi diperlukan gambaran terkait kandungan bahan berbahaya yang terkandung dalam perhiasan imitasi melalui review hasil penelitian penelitian terkait dengan kandungan bahan pada perhiasan imitasi yang murah, jenis jenis bahan berbahaya, pengaruh bahan berbahaya bagi tubuh. Untuk menggambarkan besarnya perhiasan imitasi yang beredar di pasaran dicari dari nilai perdagangan perhiasan imitasi yang diperoleh dari www.trademap.org. Jika telah tergambar besarnya nilai perdagangan perhiasan imitasi, maka dicari ketersediaan regulasi standar melalui website BadanStandardisasiNasional (BSN) yaitu www.sispk.bsn.go.id serta perbandingan standar di luar negeri melaluipencaria di internet. Sumber data yang digunakan dalam penelitian ini adalah data sekunder yang berasal dari regulasi, hasil penelitian, kajian, laporan yang bersumber dari internet, jurnal dan lain sebagainya.

\section{HASIL DAN PEMBAHASAN}

\section{a. Tinjauan Aspek Kesehatan}

Dugaan adanya kandungan logam berbahaya yang terdapat pada perhiasan imitasi dirujuk dari beberapa penelitian yang telah dilakukan di luar negeri. Beberapa penelitian tersebut diantaranya adalah penelitian dari Prof Jeffrey Wiedenhamer yang mengungkapkan adanya zat - zat berbahaya yang terkandung dalam perhiasan imitasi. Menurut Prof. Jeffrey 
Wiedenhamer dalamperhiasan imitasi impor ditengarai mengandung logam - logam berbahaya seperti cadmium, lead/timbal, arsenic dan lainnya. Penelitian dilakukan dengan membeli sejumlah perhiasan sebanyak 99 barang dari retail Claire, Forever 21dan H\&M, di beberapa tempat di Amerika Serikat. Hasil peneitian menemukan bahwa dari 99 perhiasan yang dibeli, 25 persennya mengandung bahan baku berbahaya. Kadarnya juga telah melewati batas yang ditentukan oleh Komisi Perlindungan Konsumen(Aguslia, 2012).

Penelitian yang dilakukan oleh Mass et. al (2005) tentang dugaan kandungan timbal $(\mathrm{Pb})$ pada low-cost jewelry. Mass et.al meneliti 285 perhiasan dari 20 toko yang berbeda. Perhiasan yang diambil adalah dalam dua klasifikasi umur, yaitu anak - anak dan dewasa. Peneitian ini dilakukan di Amerika. Untuk menilai kandungan logam timbal, dilakukan dengan pengujian flame atomic absorption spectroscopy (FAAS). Hasil yang didapatkan oleh Mass et. al. menemukan setidaknya $40 \%$ dari 311 bagian perhiasan yang diuji mempunyai kandungan timbal tidak kurang dari $50 \%$, dan $10 \%$ lainnya mengandung lebih dari $75,0 \%$ timbal (Maas, Patch, Pandolfo, Druhan, \& Gandy, 2005). Penelitian serupa juga dilakukan oleh Thyssen et. al. (2019) kandungan logam yang diteliti adalah nikel pada inexpensive jewelry. Thyssen et. al. meneliti terhadap perhiasan yang murah di 36 toko dan pedagang jalanan di Copenhagen Denmark. Metode pengujian nikel yang digunakan oleh Thyssen et. al. adalah pengujian dengan dimethylglyoxime (DMG). Hasil yang didapatkan 19,3\% jepit rambut, $14,8 \%$ anting dan $12,9 \%$ kalung untuk orang dewasa mengeluarkan nikel yang berlebihan. Dari 25 toko yang dikunjungi sebanyak $36 \%$ menjual perhiasan positif DMG. Sedangkan perhiasan yang ditujukan untuk anak - anak diidentifikasi dalam jepit rambut $(79,4 \%)$ dan dalam cincin $(20 \%)$. Dan $50 \%$ dari 8 toko pakaian anak - anak menjual perhiasan yang melepaskan terlalu banyak nikel (Thyssen, Menné, \& Duus, 2009). Peneliti lain yang meneliti kandungan zat berbahaya pada perhiasan imitasi adalah Cui et. al. (2015) (Cui, Li, Zhang, Fan, \& Ma, 2015).

Menurut Widaningrum et. al. (2007) akumulasi logam berat di dalam tubuh manusia dalam jangka waktu yang lama akan mengganggu system peredaran darah, urat syaraf dan kerja ginjal (Widaningrum, Miskiyah, \& Suismono, 2007). Cadmium sebagai logam berat yang berbahaya bagi tubuh manusia jika terpapar juga diteiti oleh
Sethi dan Khandelwal (2006). Menurut Sheti dan Khandelwal, Cadmium sebagai bahan neurotoxic dan nephorotexic. Ini sudah disadari oleh negara maju, namun belum disadari oeh negara - negara berkembang seperti India. Penelitian Sethi dan Khandelwal berawal dari seorang pria berusia 32 tahun menemui mereka. Pria tersebut adalah seorang pekerja di sebuah perusahaan perhiasan. Pria tersebut menrasakan sakit pada pergelangan sendi kaki hingga ke tulang rusuk selama satu tahun terakhir. Namun setelah diteliti, penyakitnya tidak terkait dengan pembengkakan pada kaki. Selanjutnya hasil uji AAS pada urine pria tersebut ternyata mengandung 20,10 microgram cadmium per liter (normal $<5,00$ $\mathrm{mcg} / \mathrm{l})$. Ini disebabkan oleh kebiasaanya dalam bekerja sebagai tukang perhiasan perak dengan mencampur perak dengan 30\% cadmium untuk membuat perhiasan perak. Selama proses pematrian/pengelasan perhiasan perak, tidak disadari ada asap cadmium yang terhirup oleh pasien dan keluarganya (Sethi \& Khandelwal, 2006).

Yost dan Weidenhamer (2008) meneliti kandungan logam berbahaya pada plastic jewelry, menurut Yost dan Weidenhamer (2008) 9 dari 103 item yang diuji mengandung lebih besar dari 30 ugram nitric acid extractable lead per bead(Yost \& Weidenhamer, 2008). Menurut Pontoppidan, dkk (2009) meneliti pemaparan logam nikel pada perhiasan murah dan jepit rambut. Hasilnya 22,0\% dari 354 bagian logam perhiasan dan aksesoris mengandung nickel (Thyssen et al., 2009)

Penelitian yang dilakukan oleh Xin-Yi Cui dkk (2015) menemukan kandungan As sebesar 0,22 - 19 ; Cd sebesar 0,01 -139; Sb sebesar 0,1-189; Cr sebesar 0,06-846; $\mathrm{Pb}$ sebesar 0,14 - 2894 dan $\mathrm{Pb}$ sebesar 0,08 $860 \mathrm{mg} / \mathrm{kg}$. Penelitian ini dilakukan terhadap 45 sampel mainan dan perhiasan anak(Cui et al., 2015)

Penulis telah melakukan penelitian pada tahun 2011 dengan cara menguji kandungan kadmium dan timbale pada perhiasan imitasi menggunakan metode AAS. Peneliti menemukan kandungan logam kadmium dan timbal pada perhiasan bross imitasi di Yogyakartamengandunglogam timbal ditemukan sebesar $63,67 \%$ sedangkan kandungan cadmium sebesar $0,0075 \%$. Kandungan logam berbahaya ini berasal dari bahan baku yang digunakan untuk perhiasan imitasi (Setiawan, 2011). Untuk mendapatkan harga perhiasan yang murah, produsen menggunakan bahan yang murah seperti timbal sebagai campuran bahan pewter, 
PenilaianKebutuhanStandarPerhiasan Imitasi

kemudian dilakukan pelapisan dengan logam lain yang lebih bagus seperti emas atau perak.

Efek logam berbahaya bagi tubuh diungkapkan oleh peneliti - peneliti berikut ini, akumulasi logam berat di dalam tubuh manusia dalam jangka waktu yang lama dapat mengganggu system peredaran darah, urat syaraf dan kerja ginjal (Widaningrum et al., 2007).

ASTDR (Agency for Toxic Substance and Disease Registry) menerangkan bahwa tujuan utama dari profil Interaksi ini untuk timbal, arsenik, kadmium, dan kromium adalah untuk mengevaluasi data tentang toksikologi baik itu campuran dari bahan kimia dalam campuran untuk merekomendasikan pendekatan dalam menilai potensi bahaya dari campuran ini untuk kesehatan masyarakat (ASTDR, 2004).

Efek yang berpotensi akan terjadi akibat dari terpaparnya logam timbal, arsenic, cadmium dan chromium adalah gangguan pada neurological, hematological, cardiovascular, renal, testicular dan kanker (ASTDR, 2004).

Berdasarkan temuan - temuan logam berbahaya yang terdapat pada perhiasan imitasi dan mengetahui akibat terpaparnya logam berbahaya bagi tubuh, maka pemerintah harus memikirkan regulasi untuk mengatur kualitas produk perhiasan imitasi yang beredar di pasaran Indonesia.

Perlu ditekankan juga bahwa standar ini menyangkut kesehatan, keselamatan, keamanan dan lingkungan (K3L).

\section{b. TinjauanAspek Perdagangan}

Berdasarkan data dari International Trade Center yang diolah, tercatat nilai ekspor dan impor perhiasan imitasi Indonesia ke Negara di ASIA dan dunia dengan kode HS 7117 tersaji pada Gambar 1 dan Gambar 2

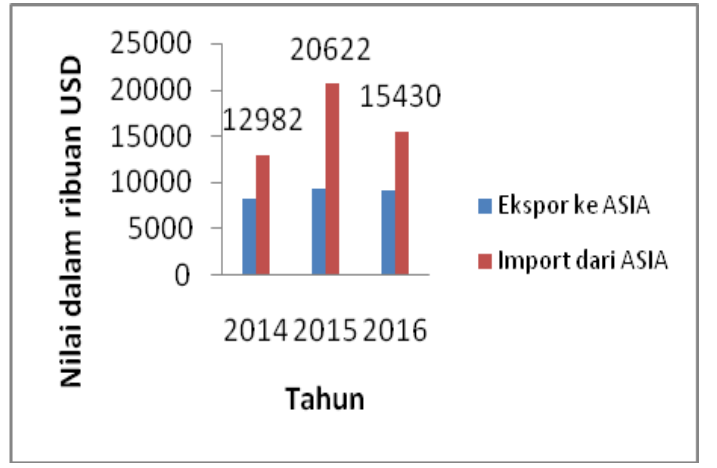

Gambar 1. Nilai Ekspor dan Impor Perhiasan imitasi Indonesia ke asia.

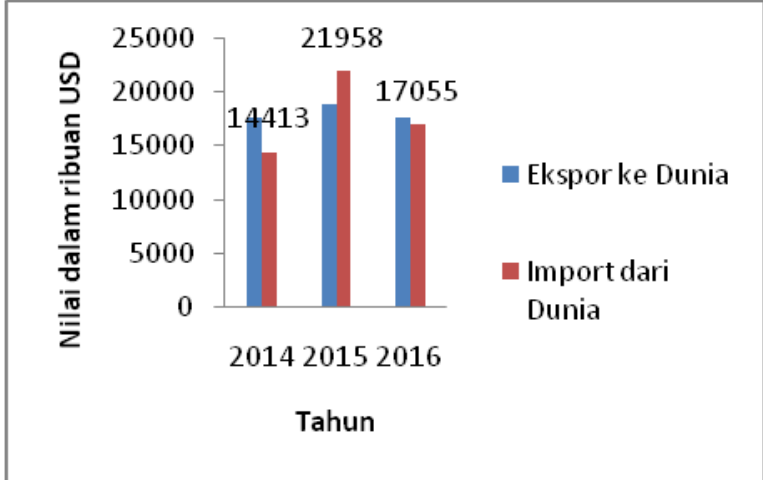

Gambar 2. Nilai Ekspor dan Impor Perhiasan Imitasi Indonesia ke Dunia

Pada Gambar 1 menyajikan perbandingan impor dan ekspor produk sesuai HS 7117 Perhiasan imitasi. Nilai impor Indonesia yang berasal dari ASIA lebih besar jika dibandingkan nilai ekspornya. Pada Gambar 2 menunjukkan nilai import barang perhiasan imitasi Indonesia tidak terpaut banyak dari nilai impor dari seluruh dunia. Ini menunjukkan bahwa sebagian besar produk impor perhiasan imitasi Indonesia berasal dari ASIA. Negara - negara ASIA yang besar nilai ekspornya ke luar adalah China. Dengan masuknya produk impor, jika di dalam negeri tidak ada regulasi yang mengatur produk tersebut dari segi kualitas dan kandungan zat - zat yang berbahaya, maka dapat merugikan konsumen di Indonesia.

\section{c. Tinjauan Ketersediaan SNI}

Dalam menilai aspek ketersediaan SNI data dapat dicari pada database SNI melalui sistem informasi dari Badan Standardisasi Nasional (BSN) dengan alamat website www.sispk.bsn.go.id dengan kata kunci perhiasan, imitasi, perak dan emas yang disajikan pada Tabel 1.

Pada Tabel 1 SNI yang terkait dengan perhiasan berjumlah delapan SNI. Standar tersebut baru mengatur barang - barang emas, barang - barang emas muda, barang barang perak, kawat perak, mutiara, dan batu mulia. Rata - rata usia SNI tersebut juga sudah lebih dari lima tahun dan berdasarkan Pedoman Standardisasi Nasional (PSN) perlu untuk ditinjau kembali sekurang - kurangnya lima tahun. Dari SNI tersebut juga belum ada yang mengatur tentang perhiasan imitasi.

Pada Tabel 1 disajikan daftar SNI terkait dengan perhiasan. SNI yang mengatur perhiasan dengan logam mulia telah ada yaitu SNI 13-3487-2005 Barang-barang emas dan SNI 13-3771-1995 Barang-barang emas muda. SNI ini termasuk SNI yang sudah lama dan perlu dilakukan peninjauan kembali. Selain itu 
SNI 0319:2014 Barang-barang perak dan SNI 7715.1:2014 Kawat perak sebagai bahan baku siap produk kerajinan - Bagian 1:Penampang lingkaran telah ada dan termasuk SNI baru yang diterbitkan pada tahun 2014. Selain SNI tersebut diatas tidak ada lagi SNI yang mengatur tentang bahan baku perhiasan.SNI perhiasan masuk dalam Komite Teknis 39-01
Perhiasan. Dan pada saat ini Komite Teknis tersebut belum melakukan kajian lagi terhadap SNI - SNI yang sudah lama.

Indonesia telah memiliki SNI ISO 8124-3 : 2010 Keamanan mainan - Bagian 3: Migrasi unsure tertentu SNI ini merupakan adopsi dari ISO 8124.

Tabel 1. Daftar SNI yang terkait perhiasan

\begin{tabular}{|c|c|c|c|}
\hline No & Produk & SNI & Judul \\
\hline 1 & Emas dan Perak & SNI 13-3610-1994 & $\begin{array}{l}\text { Penentuan emas dan perak di dalam } \\
\text { batuan dengan cara fire assay }\end{array}$ \\
\hline 2 & Emas & SNI 13-3771-1995 & Barang-barang emas muda \\
\hline 3 & Emas & SNI 13-3487-2005 & Barang-barang emas \\
\hline 4 & Perak & SNI 7715.1:2014 & $\begin{array}{l}\text { Kawat perak sebagai bahan baku siap } \\
\text { produk kerajinan }- \text { Bagian } 1: \\
\text { Penampang lingkaran }\end{array}$ \\
\hline 5 & Perak & SNI 0319:2014 & Barang-barang perak \\
\hline 6 & Mutiara & SNI 4989:2011 & Mutiara laut selatan \\
\hline 7 & Mutiara air tawar & SNI 7845:2013 & $\begin{array}{l}\text { Mutiara air tawar (freshwater pearl) - } \\
\text { Syarat mutu dan penanganan }\end{array}$ \\
\hline 8 & Batu mulia & SNI 13-6339.6-2000 & $\begin{array}{l}\text { Istilah komoditas mineral dan batubara } \\
\text { - Bagian F: Batu mulia }\end{array}$ \\
\hline
\end{tabular}

\section{d. Aspek Perbandingan dengan Standar Internasional}

Untuk menilai kebutuhan SNI Perhiasan imitasi, salah satu aspek yang perlu dipertimbangkan dengan membandingkan standar internasional yang berlaku di negara lain. Beberapa negara yang telah menerapkan persyaratan untuk prorduk perhiasan imitasi, diantaranya adalah Uni Eropa, Amerika, China, Australia, Jepang, Singapura dan lain sebagainya. Di negara-negara tersebut sudah diterapkan standar keamanan untuk produk perhiasan imitasi atau lebih spesifik lagi yaitu standar produk perhiasan untuk anak-anak diantaranya adalah sebagai berikut:

Tabel 2. Standar yang berlaku di beberapa negara

\begin{tabular}{|c|c|c|c|c|}
\hline No & Produk & Standar & Judul & Berlaku \\
\hline 1 & $\begin{array}{l}\text { Perhiasan untuk } \\
\text { anak-anak }\end{array}$ & ASTM F2923 & $\begin{array}{l}\text { Standard Specification for } \\
\text { Consumer Product Safety for } \\
\text { Children's Jewelry }\end{array}$ & Amerika \\
\hline 2 & $\begin{array}{l}\text { Mainan dan } \\
\text { perhiasan anak }\end{array}$ & EN 71 part 3 & Migration of certain elements & Uni Eropa \\
\hline 3 & $\begin{array}{l}\text { Mainan dan } \\
\text { perhiasan anak }\end{array}$ & ISO $8124: 3$ & Migration of certain elements & Internasional \\
\hline 4 & $\begin{array}{l}\text { Mainan dan } \\
\text { perhiasan anak }\end{array}$ & $\begin{array}{l}\text { AZ/NZS } \\
8124.3: 2013\end{array}$ & Migration of certain elements & $\begin{array}{l}\text { Australia dan } \\
\text { New Zeland }\end{array}$ \\
\hline
\end{tabular}




\section{KESIMPULAN}

Kesimpulan dari penelitian ini adalah terdapat kandungan logam berbahaya pada perhiasan imitasi di Amerika, Denmark, Indonesia Nilai perdagangan perhiasan imitasi di Indonesia cukup besar dan nilai impor Indonesia lebih besar daripada nilai ekspornya sehingga banyak barang perhiasan imitasi impor dari negara Asia dan dunia. Walaupun standar khusus perhiasan imitasi di Indonesia belum ada, namun Indonesia telah meberlakukan standar SNI ISO 8124-3:2010 Keamanan mainan - Bagian3 :Migrasi unsure tertentu yang berlaku pada mainan anak. Beberapa negara antara lain Amerika, Australia, New Zeland, Uni Eropa telah menerapkan standar kandungan logam berbahaya pada mainan dan perhiasan ana kberdasarkan EN 71 part 3 atau ISO 8124:3.

\section{UCAPAN TERIMAKASIH}

Kami ucapkan terima kasih yang sebesarbesarnya kepada Kepala Balai Besar Kerajinan dan Batik, Kepala Bidang Sarana Riset dan Standardisasi dan Kepala Seksi Standardisasi.

\section{DAFTAR PUSTAKA}

Aguslia. (2012). Perhiasan Imitasi Sebabkan Alergi Kulit. Retrieved April 10, 2018, from https://gaya.tempo.co/read/393272/perhia san-imitasi-sebabkan-alergi-kulit

ASTDR. (2004). Interaction Profile for Toxic Substances. Retrieved July 26, 2018, from

https://www.atsdr.cdc.gov/interactionprofil es/ip-metals1/ip04-c1.pdf

Cambridge. (2018a). Imitation. Retrieved April 10, 2018, from https://dictionary.cambridge.org/dictionary/ english/imitation

Cambridge. (2018b). Jewellery. Retrieved April 10, 2018, from https://dictionary.cambridge.org/dictionary/ english/jewellery

Cui, X., Li, S., Zhang, S., Fan, Y., \& Ma, L. Q. (2015). Toxic metals in children â€TM s toys and jewelry: Coupling bioaccessibility with risk assessment. Environmental Pollution, 200, 77-84. https://doi.org/10.1016/j.envpol.2015.01.0 35

Dewi, L. S. (2010). Trend dan Daya Beli Masyarakat IndonesiaTerhadap Perhiasan Logam Mulia. VICIDI, 1(1).
Faozi, M. M., \& Mufidah, A. (2018). Penawaran Produk Imitasi Jenis Fashion dan Proses Pengambilan Keputusan Konsumen di Pasar Kaget Stadion Bima Cirebon. AlMustashfa: Jurnal Penelitian Hukum Ekonomi Islam, 3(2), 254-267.

Grynkiewicz-bylina, B., Migracji, B., Pierwiastk, T., \& Pow, S. J. (2011). Testing of Toxic Elements Migration from The Materials Used As Toy Coatings, 18(2).

ISO. (2019). Standards. Retrieved September 28, 2019, from https://www.iso.org/standards.html

ISO, (2010). SNI ISO 8124-3:2010 Keamanan mainan - Bagian 3: Migrasi unsur tertetntu

KBBI. (2018a). Kamus Besar Bahasa Indonesia. Retrieved April 10, 2018, from https://kbbi.kemdikbud.go.id/entri/perhiasa $\mathrm{n}$

KBBI. (2018b). Kamus Besar Bahasa Indonesia. Retrieved April 10, 2018, from https://kbbi.kemdikbud.go.id/entri/imitasi

Maas, R. P., Patch, S. C., Pandolfo, T. J., Druhan, J. L., \& Gandy, N. F. (2005). Lead Content and Exposure from Children 's and Adult's, (December 2004), 437444. https://doi.org/10.1007/s00128-0050605-3

Sethi, P. K., \& Khandelwal, D. (2006). Cadmium Exposure: Health Hazards of Silver Cottage Industry in Developing Countries,2(1), 14-15.

Setiawan, J. (2011). Penelitian Kandungan Cadmium (Cd) dan Timbal (Pb) pada Perhiasan Imitasi. Dinamika Kerajinan Dan Batik, 30, 25-29.

Sholeh, M. (2014). Emas sebagai Intrumen Investasi Yang Aman Pada Saat Instrumen Investasi Keuangan Lain Mengalami Peningkatan Resiko. Jurnal Akuntansi UNESA, 2(2), 1-20.

Sinabutar. (2013). Market Brief Peluang Perhiasan Imitasi di Italia. Jakarta. Retrieved from http://djpen.kemendag.go.id/app_frontend/ admin/docs/researchcorner/31013762998 04.pdf

Street, L., Gopaul, K., Kumar, M., Lu, C., \& Hewitt, A. (2017). Gold Demand Trends Full Year 2016 A four-year high in investment drove price gains and demand growth Jewellery Hit by high gold prices, annual jewellery demand fell to a, (February), 1-14.

Thyssen, J. P., Menné, T., \& Duus, J. (2009). Nickel Release from Inexpensive Jewelry and Hair Clasps Purchased in an EU Country - Are consumers suf fi ciently protected from nickel exposure? Science of the Total Environment, The, 407(20), 
5315-5318.

https://doi.org/10.1016/j.scitotenv.2009.06 .034

Widaningrum, Miskiyah, \& Suismono. (2007).

Bahaya Kontaminasi Logam Berat dalam Sayur dan Alternatif Pencegahan Pencemarannya. Buletin Teknologi Pascapanen Pertanian, 3.

Yost, J. L., \& Weidenhamer, J. D. (2008). Lead Contamination of Inexpensive Plastic Jewelry. Science of The Total Environment, 393(2-3), 348-350. 
